\title{
Quality and quantity of chicory, lucerne and red clover production under irrigation
}

\author{
H.E. BROWN and D.J. MOOT \\ Agriculture and Life Sciences Division, P.O. Box 84, Lincoln University. \\ moot@lincoln.ac.nz
}

\begin{abstract}
The quality and quantity of production from irrigated lucerne, chicory and red clover swards were compared over six years (30 November 199630 June 2002) on a Wakanui silt loam at Lincoln University. Mean annual yields from lucerne swards ( $21 \mathrm{t} \mathrm{DM} / \mathrm{ha}$ ) were $3.9 \mathrm{t} / \mathrm{ha}$ greater than chicory and red clover over five perennial regrowth seasons. Sown species gave $100 \%$ of dry matter (DM) production in the first regrowth season, but by the fifth season sown species gave 65,55 and $0 \%$ of DM production for chicory, lucerne and red clover respectively. Utilised herbage had a similar metabolisable energy (ME) content for all three species (10.9 11.6 MJ/ $\mathrm{kg} / \mathrm{DM}$ ). The crude protein (CP) content of utilised herbage was also similar for lucerne and red clover (0.25-0.29 g/g DM), but chicory had a lower CP content $(0.18 \mathrm{~g} / \mathrm{g} \mathrm{DM})$. This combined with utilisation data to show lucerne swards provided $30 \%$ greater annual CP and $\mathrm{ME}$ intake for grazing stock than either chicory or red clover. This demonstrated the greater potential of lucerne to improve livestock production from high value land. Changes in lucerne herbage quality were also analysed within regrowth cycles to examine the influence of the time of grazing on $\mathrm{CP}$ and ME intake. The fraction of palatable lucerne herbage decreased linearly from $100 \%$ at $700 \mathrm{~kg} / \mathrm{ha}$ standing DM to $57 \%$ at $4300 \mathrm{~kg} / \mathrm{ha}$ standing DM. The CP and ME contents of the palatable fraction of lucerne herbage were always higher than the post grazing residual. This highlights the selective grazing of the stock, which consumed $80 \%$ of total CP and $70 \%$ of total ME for a crop of $4300 \mathrm{~kg} / \mathrm{ha}$ standing DM. This grazing preference shows that delaying defoliation will not reduce potential stock production, unless stock are forced to consume the low quality stem in standing herbage.
\end{abstract}

Keywords: Cichorium intybus, crude protein, herbage utilisation, Medicago sativa, metabolisable energy, pasture persistence, Trifolium pratense

\section{Introduction}

An option for high value land is to maximize animal production (milk or live weight per hectare) from intensive grazing systems based on specialist forage crops. The basis of this is to use high quality herbage to maximise live weight gains (Burke et al. 2002) and provide greater herbage production than is expected from typical ryegrass/white clover pastures (White et al. 1999). Such specialist forages may also increase farm production as supplementary feeds.

Chicory, lucerne and red clover are all high quality perennial forages that have demonstrated high herbage yields (15-28 t DM/ha/y) under irrigated (Brown et al. 2000) and dryland conditions (Brown et al. 2003). Their suitability for high value land is dependant on the annual stock production they support and the cost of maintaining this production. The potential stock production from a forage crop is a combination of the quality and quantity of herbage intake (grazed in situ or conserved for supplement) and can be implied from the annual crude protein (CP) and metabolisable energy (ME) intake it provides. The cost of production is dependant on crop persistence (frequency of renewal) and fixed costs such as weed control, fertiliser and irrigation requirements.

A further issue with annual and perennial forage crops is that the total herbage quality of forages usually decreases as herbage accumulates (Buxton 1996; Clapham et al. 2001). This trade-off between quality and quantity of feed is partially offset by grazing stock that preferentially select the more palatable fractions and leave the less palatable components (usually stems) in the paddock (Li et al. 1994; White \& Cosgrove 1990). It is not certain how delaying defoliation influences the potential stock production from these perennial forages in a grazed situation.

The aim of this paper was to quantify the potential production of chicory, lucerne and red clover from an irrigated experiment grown over a 6-year period at Lincoln University. Agronomic management data are provided to enable the costs of production to be calculated. Changes in lucerne forage quality and utilisation were also assessed within regrowth cycles to demonstrate how the timing of grazing influenced the potential production of this species.

\section{Materials and methods Management}

The experiment was conducted at Lincoln University, Canterbury, New Zealand $\left(43^{\circ} 38^{\prime} \mathrm{S}, 172^{\circ} 28^{\prime} \mathrm{E}\right.$, $11 \mathrm{~m}$ a.m.s.l.) on a Wakanui silt loam (Udic Ustochrept, USDA Soil Taxonomy) with 1.8-3.5 m of fine textured material overlying gravels (Cox 1978). It was a randomised complete block with three replicate plots (22 
Table 1 Agronomic inputs and number of grazings for perennial forages.

\begin{tabular}{|c|c|c|c|c|}
\hline Season & Herbicide (kg a.i./ha) & Fertiliser (kg/ha) & $\begin{array}{l}\text { Irrigation } \\
\quad(\mathrm{mm})\end{array}$ & $\begin{array}{l}\text { Defoliation } \\
\text { (number/y) }\end{array}$ \\
\hline $\begin{array}{l}1996 / \\
1997\end{array}$ & $\begin{array}{l}{ }^{1} \text { trifluralin, } 0.8 \\
\text { 2flumetsulum, } 0.48\end{array}$ & $\begin{array}{l}{ }^{4} \text { sulphate of potash, } 150 \\
{ }^{4} \text { superphosphate, } 250 \\
{ }^{4} \text { lime, } 4000\end{array}$ & 80 & 2 \\
\hline $\begin{array}{l}1997 / \\
1998\end{array}$ & ${ }^{3}$ bentazone/haloxyfop, $0.96 / 0.13$ & superphosphate, 200 & 306 & 6 \\
\hline $\begin{array}{l}1998 / \\
1999\end{array}$ & ${ }^{3}$ bentazone/haloxyfop, $0.96 / 0.13$ & & 437 & 7 \\
\hline $\begin{array}{l}1999 / \\
2000\end{array}$ & 3bentazone/haloxyfop, $0.96 / 0.13$ & potassic superphosphate, 260 & 80 & 6 \\
\hline $\begin{array}{l}2000 / \\
2001\end{array}$ & ${ }^{3}$ bentazone/haloxyfop, $0.96 / 0.13$ & sulphur superphosphate, 250 & 280 & 7 \\
\hline $\begin{array}{l}2001 / \\
2002\end{array}$ & 3bentazone/haloxyfop, $0.96 / 0.13$ & sulphur superphosphate, 200 & 65 & 6 \\
\hline
\end{tabular}

x $6.3 \mathrm{~m}$ ) of chicory ('Grasslands Puna', $3.5 \mathrm{~kg} / \mathrm{ha}$ ), lucerne ('Grasslands Kaituna', $7 \mathrm{~kg} / \mathrm{ha}$ ) and red clover ('Grasslands Pawera', $10 \mathrm{~kg} / \mathrm{ha}$ ) sown as pure swards on 30 November 1996 and surrounded by white clover guard plots. The experiment ran over 6 growth seasons (1 July-30 June) with an establishment season (1996/ 1997) and five subsequent regrowth seasons (1997/ 1998-2001/2002).

Complete experimental details were given by Brown et al. (2000, 2004). Briefly, the experimental area was prepared with conventional cultivation methods. Soil tests were conducted prior to establishment and annually during the experiment with fertiliser applied to maintain a $\mathrm{pH}>$ 6 , Olsen phosphorus $>15 \mu \mathrm{g} / \mathrm{ml}$, quick test potassium $>$ 5 and sulphate-sulphur $>10 \mu \mathrm{g} / \mathrm{g}$ (Table 1). Preliminary tests showed no nitrogen $(\mathrm{N})$ response in chicory (grazing stock transferred $\mathrm{N}$ onto chicory plots from surrounding legume plots) so $\mathrm{N}$ fertiliser was not applied to chicory. Herbicide was applied during establishment and each winter to remove annual grass and broadleaf weeds from all plots (Table 1). The herbicides were applied in common across species, which limited the combinations available in this research environment. The treatments reported in this study were all fully irrigated to maintain the soil water deficit below $200 \mathrm{~mm}$ (Brown et al. 2003) with an annual irrigation ranging from $65-437 \mathrm{~mm}$ (Table 1).

Swards were grazed in common for 3-7 days on 6-7 occasions each year. The timing of each defoliation was a compromise between the ideal management for each of the three species. In particular, management aimed to prevent extensive primary flower stem production in chicory, allow lucerne to reach $\sim 20 \%$ flowering at least once in the autumn and minimize red clover flower stem thickening in summer. Any residual stem was trimmed to $\sim 70 \mathrm{~mm}$ above ground level on the day grazing finished.

\section{Measurements}

Herbage accumulation was measured for each sward at 7-10 day intervals throughout each regrowth cycle and yields were determined from a final cut taken on the day sheep were introduced for grazing. Post-grazing herbage residual was cut immediately after the removal of sheep to calculate herbage utilisation. Dry matter (DM) measurements were based on a $0.2 \mathrm{~m}^{2}$ quadrat, cut to crown height with a set of hand shears from each plot.

Botanical composition of each sward was determined after weed invasion became significant in the third regrowth season (1999/2000). Sub-samples of at least $50 \mathrm{~g}$ fresh weight were taken from final cuts of each regrowth cycle and separated into sown forage species and weed fractions. Weeds were predominantly white clover but dandelion and shepherds's purse became prominent in red clover plots in the fourth and fifth regrowth seasons.

Palatable and unpalatable fractions of the sown species were separated from herbage samples for determining nutritive value of final cuts throughout the experiment and all cuts within each regrowth cycle of the $2000 / 2001$ season. The palatable fraction was defined as all the herbage that stock would consume (leaves and soft upper stems). The unpalatable fraction was the 
lignified lower stems that would be left in the paddock as residual after grazing. Red clover stems were always succulent at the time of grazing so all red clover herbage was considered palatable. The unpalatable fraction of chicory was determined by separating hardened stems from the entire herbage sample. The unpalatable fraction of lucerne was determined from a sub-sample. These were separated into short $(<0.1 \mathrm{~m})$, medium $(<0.3 \mathrm{~m})$ and long $(>0.3 \mathrm{~m})$ stems and representative numbers taken from each height class to make up a sub-sample of 10-12 stems. Each lucerne sub-sample was then separated using the 'breaking-point method', where the apex of each stem was bent back and pulled down the length of the stem until it broke. The section of stem from above this breaking point plus all leaves were considered palatable and the lignified stem below the breaking point unpalatable. Confirmation of the accuracy of this separation method was obtained by comparing nutritive values of the sampled unpalatable fraction with the residual herbage cut from the plots post-grazing.

The nutritive value of herbage was determined for palatable, unpalatable and weed fractions from final cuts and residual from post-grazing cuts from a total of 12 regrowth cycles throughout the five regrowth seasons. Nutritive value was also assessed on palatable and unpalatable fractions of all lucerne cuts within each regrowth cycle in the 2000/2001 season. Dried samples were pooled (i.e. all three replicates combined), ground to pass through a $1 \mathrm{~mm}$ mesh in a Cyclotec 1093 sample mill and sub-sampled for nutritive analysis. Nitrogen content was determined using the Kjeldahl method and multiplied by a factor of 6.25 to give values for crude protein $(\mathrm{CP})$ content of herbage $(\mathrm{g} / \mathrm{g} \mathrm{DM})$. The metabolisable energy (ME) content of herbage (MJ/ $\mathrm{kg} \mathrm{DM}$ ) was calculated from in-vitro organic matter digestibility.

The annual intake of CP (t/ha) and ME (GJ/ha) by grazing stock were calculated from annual herbage DM yields, the long-term means of nutritive values for each herbage fraction and herbage utilisation (Brown 2004).

\section{Statistical analysis}

Annual herbage yields, weed composition, herbage utilisation and $\mathrm{CP}$ and ME intakes were analysed using a split-plot ANOVA with species (chicory, lucerne and red clover) as the main-plot and regrowth season (1997/ 1998-2001/2002) as the sub-plot (repeated measure). Standard errors of the mean were calculated to compare species means both within and between seasons. Single factor ANOVA was also conducted within each regrowth season to allow more sensitive comparison of species differences. The $\mathrm{CP}$ and $\mathrm{ME}$ contents were from pooled replicates so did not allow ANOVA. However, there was no systematic change apparent in these nutritive values within or between regrowth seasons so standard errors were calculated for the means of all five years data.

The quality of lucerne herbage within regrowth cycles was analysed by fitting regressions to $\mathrm{CP}$ and $\mathrm{ME}$ contents against the amount of standing herbage. The $\mathrm{CP}$ content of the palatable fraction was described with an exponential regression of the form $y=a+b * \exp (-$ $\left.\mathrm{c}^{*} \mathrm{DM}\right)$. The $\mathrm{CP}$ of unpalatable fraction and the ME content of both fractions were described by linear regressions. The percentage of palatable to unpalatable lucerne herbage was analysed by regression against the total standing lucerne herbage. Similarly, the proportions of lucerne $\mathrm{CP}$ and $\mathrm{ME}$ in the palatable fraction were regressed against total $\mathrm{CP}$ and $\mathrm{ME}$ in standing herbage.

\section{Results}

\section{Annual yields, weed composition and utilisation}

The total annual herbage yield was always highest $(\mathrm{P}<0.01)$ from lucerne swards but decreased from $28 \mathrm{t} \mathrm{DM} /$ ha in the first regrowth season $(1997 / 1998)$ to $17 \mathrm{t} \mathrm{DM} /$ ha in the fifth (Figure 1a). These annual yields were 3-9 t DM/ha greater $(\mathrm{P}<0.01)$ than for chicory and

Table 2 Crude protein (g/g DM) and ME (MJ/kg DM) contents of herbage fractions (palatable, unpalatable and weed) and post-grazing residual of chicory, lucerne and red clover swards grown over five years. Values in parenthesis are standard errors for each mean calculated from five year's data.

\begin{tabular}{llcccc}
\hline & Species & Palatable & Unpalatable & Weed & Residual \\
\hline $\mathrm{CP}$ & Chicory & $0.18(0.011)$ & $0.08(0.013)$ & $0.25(0.011)$ & $0.10(0.010)$ \\
& Lucerne & $0.29(0.008)$ & $0.12(0.008)$ & $*$ & $0.12(0.013)$ \\
& Red clover & $0.25(0.011)$ & & $*$ & $0.20(0.009)$ \\
$\mathrm{ME}$ & Chicory & $11.3(0.20)$ & $9.4(1.39)$ & $11.4(0.33)$ & $8.6(0.67)$ \\
& Lucerne & $11.6(0.13)$ & $7.8(0.42)$ & $*$ & $6.8(0.55)$ \\
& Red clover & $10.9(0.21)$ & & $*$ & $10.0(0.09)$ \\
\hline
\end{tabular}

${ }^{*}$ Weed fractions not analysed. 
Figure 1 Total annual herbage yields (a), stock utilisation (b) and botanical composition (c) of chicory (๑), lucerne ( $\square$ ) and red clover $(\triangle)$ swards grown over five regrowth seasons (1 July 1997-30 June 2002). Bars represent one SEM for each regrowth season when values were different.

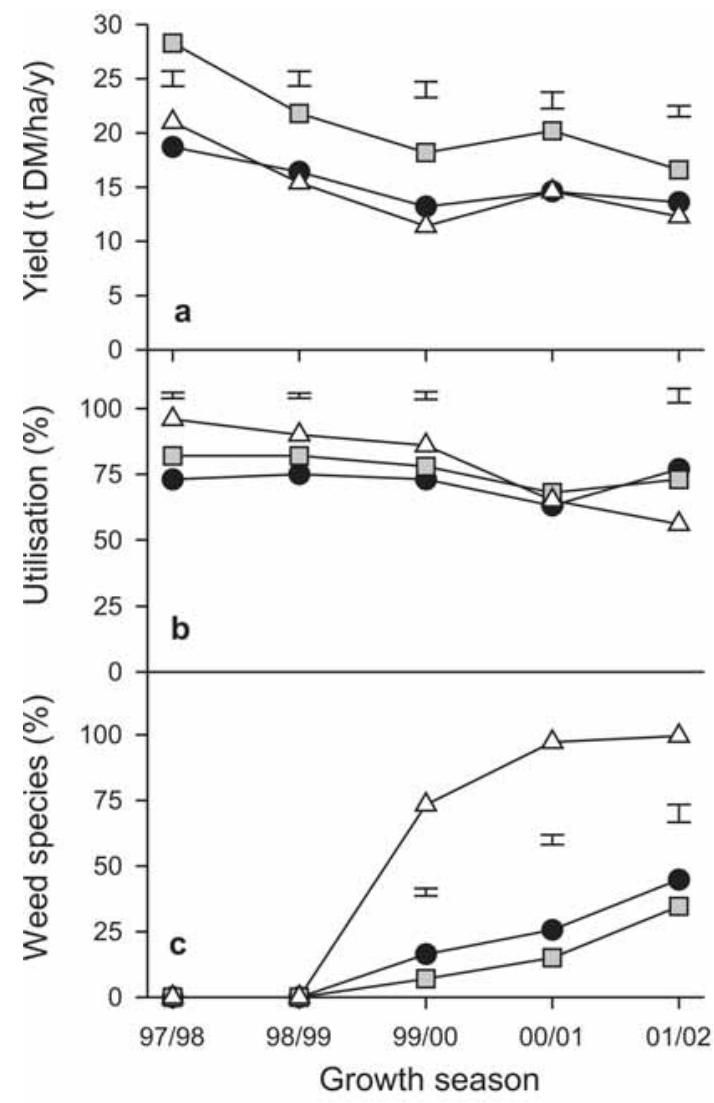

red clover swards, which both decreased from 20 to $13 \mathrm{t} \mathrm{DM} /$ ha over the same period.

Annual herbage utilisation from red clover swards $(86-96 \%)$ was greater $(\mathrm{P}<0.001)$ than chicory swards (73-75\%) in the first three seasons (1997/1998-1999/ 2000 ) with lucerne intermediary at $80 \%$ (Figure 1b). However, herbage utilisation from red clover swards declined $(\mathrm{P}<0.001)$ to the same level as chicory and lucerne swards $(65 \%)$ in the fourth season. By the fifth season (2001/2002) red clover swards were predominantly weeds and its utilisation $(56 \%)$ was lower $(\mathrm{P}<0.001)$ than for chicory $(77 \%)$ or lucerne $(72 \%)$ swards. There was substantial variation in utilisation within regrowth seasons depending on the growth stage when grazing began and grazing severity.

All three species maintained pure swards in the first two regrowth seasons (Figure 1c) but weed invasion began in the third (1999/2000). Red clover swards had the greatest $(\mathrm{P}<0.001)$ weed invasion with weeds making up $73 \%$ of total herbage yield in 1999/2000 and $95-100 \%$ of DM yield in the fourth and fifth regrowth seasons $(2000 / 2001$ and $2001 / 2002)$. Weed invasion was less $(\mathrm{P}<0.001)$ in chicory and lucerne swards, contributing $35 \%$ of total herbage yield in the fifth season $(2001 / 2002)$.

\section{Nutritive value}

The mean CP content (Table 2) in the palatable fraction of forages was highest for lucerne $(0.29 \mathrm{~g} / \mathrm{g} \mathrm{DM})$ followed by red clover $(0.25 \mathrm{~g} / \mathrm{g} \mathrm{DM})$ and chicory $(0.17 \mathrm{~g} / \mathrm{g} \mathrm{DM})$. The palatable fraction had a substantially higher $\mathrm{CP}$ content than the unpalatable fractions for chicory $(0.08 \mathrm{~g} / \mathrm{g} \mathrm{DM})$ and lucerne $(0.12 \mathrm{~g} / \mathrm{g} \mathrm{DM})$. The weed fraction of chicory (white clover) had a CP content of $0.25 \mathrm{~g} / \mathrm{g} \mathrm{DM}$, similar to red clover. The $\mathrm{CP}$ content of post-grazing residual herbage of chicory $(0.10 \mathrm{~g} / \mathrm{g} \mathrm{DM})$ and lucerne $(0.12 \mathrm{~g} / \mathrm{g} \mathrm{DM})$ were similar to the $\mathrm{CP}$ content of the unpalatable fractions of these two crops.

The ME content of the palatable fraction was similar for chicory $(11.3 \mathrm{MJ} / \mathrm{kg} \mathrm{DM})$, lucerne $(11.6 \mathrm{MJ} / \mathrm{kg}$ $\mathrm{DM}$ ), red clover (10.9 MJ/kg DM) and weeds (Table 2). The unpalatable fractions had a ME content of 9.4 MJ/kg DM for chicory and $7.8 \mathrm{MJ} / \mathrm{kg}$ DM for lucerne, which were similar to those for their postgrazing residuals.

\section{Annual protein and energy intake}

Annual CP intake from lucerne swards (3.3-6.3 t/ha) was 1.0-3.6 t CP/ha greater $(\mathrm{P}<0.01)$ than chicory and red clover in all five regrowth seasons (Figure $2 \mathrm{a}$ ). In

Figure 2 Annual crude protein (a) and metabolisable energy (b) intake by grazing stock from chicory $(\boldsymbol{\square})$, lucerne $(\square)$ and red clover $(\square)$ swards for each of five regrowth seasons. Bars represent one SEM for each regrowth season when values were different.

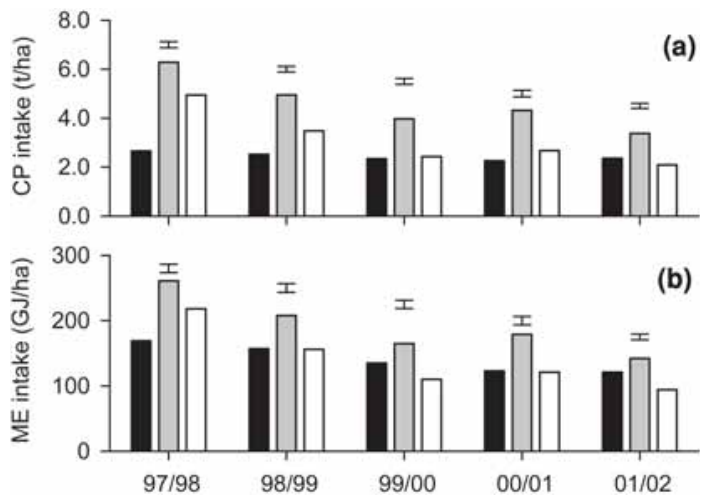


Table 3 Regression equations fitted to CP and ME content (Figure 3 ) and \% total herbage, CP and ME in the palatable fraction (Figure 4) against standing DM. Values in parenthesis are standard errors of parameters.

\begin{tabular}{lclc}
\hline Variable & Units & \multicolumn{1}{c}{ Regression } & $\mathrm{R}^{2}$ \\
\hline Palatable CP & $\mathrm{g} / \mathrm{g} \mathrm{DM}$ & $=0.26(0.134)+0.19(0.0051){ }^{*} \exp \left(-9^{-5}\left(4^{-6}\right){ }^{*} \mathrm{DM}\right)$ & 0.73 \\
1Unpalatable CP & $\mathrm{g} / \mathrm{g} \mathrm{DM}$ & $=0.11(0.043)+0{ }^{*} \mathrm{DM}$ & - \\
${ }^{1}$ Palatable ME & $\mathrm{MJ} / \mathrm{kg} \mathrm{DM}$ & $=11.9(0.09)+0{ }^{*} \mathrm{DM}$ & - \\
1Unpalatable ME & $\mathrm{MJ} / \mathrm{kg} \mathrm{DM}$ & $=7.9(0.16)+0{ }^{*} \mathrm{DM}$ & - \\
Palatable herbage & $\%$ & $=1.09(0.028)-0.012(0.0011){ }^{*} \mathrm{DM}$ & 0.71 \\
Palatable CP & $\%$ & $=1.05(0.006)-0.006(0.0002){ }^{*} \mathrm{DM}$ & 0.97 \\
Palatable ME & $\%$ & $=1.05(0.005)-0.008(0.0002){ }^{*} \mathrm{DM}$ & 0.99 \\
\hline
\end{tabular}

${ }^{1}$ slope not significantly $(\mathrm{P}<0.05)$ different from zero.

1997/1998 and 1998/1999 (when swards were still pure) sheep consumption from lucerne swards was $1.3 \mathrm{t} \mathrm{CP} /$ ha greater than from red clover and $2.4 \mathrm{t} / \mathrm{ha}$ greater than chicory. There was a decline in annual CP intake over the duration of the experiment with chicory swards decreasing from $2.7 \mathrm{t} /$ ha in $1997 / 1998$ to $1.9 \mathrm{t} /$ ha in $2001 / 2002$, lucerne decreasing from 6.3 to $3.4 \mathrm{t} / \mathrm{ha}$ and red clover decreasing from 4.9 to $1.7 \mathrm{t} /$ ha over the same period. Annual ME intake followed the same pattern with greater $(\mathrm{P}<0.001)$ intake from lucerne crops (142-261 GJ/ha) than chicory (99$169 \mathrm{GJ} / \mathrm{ha}$ ) and red clover (74-218 GJ/ha) for all five regrowth seasons (Figure $2 \mathrm{~b}$ ).

Figure 3 Crude protein (a) and ME content (b) of palatable $(\bullet)$ and unpalatable $(\bigcirc)$ fractions of lucerne herbage in relation to total standing herbage accumulated during different regrowth cycles for crops. Parameters from regressions are presented in Table 3.

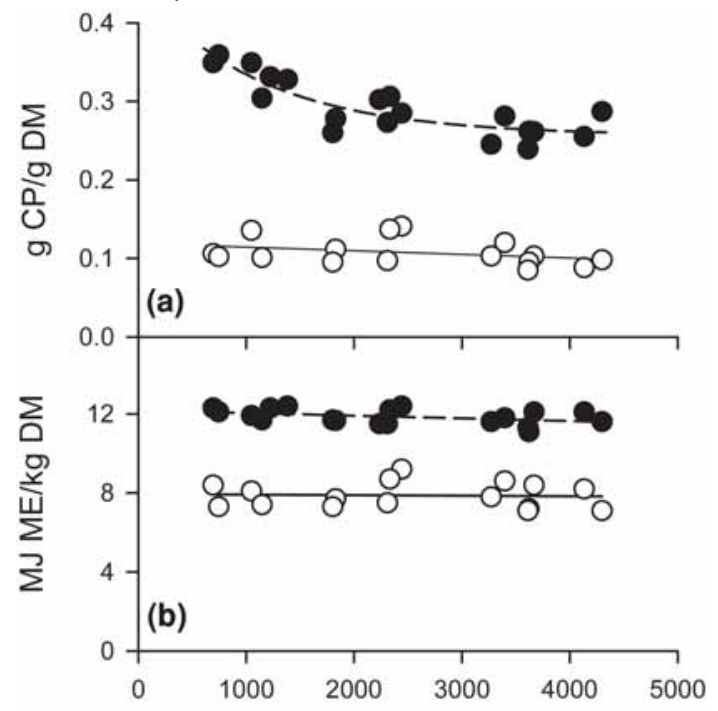

Standing herbage ( $\mathrm{kg} \mathrm{DM} / \mathrm{ha})$
Lucerne quality within individual regrowth cycles

The CP content of the palatable fraction of lucerne showed an exponential decrease (Table 3 ) from $0.35 \mathrm{~g} / \mathrm{g}$ DM to a stable $0.27 \mathrm{~g} / \mathrm{g}$ DM as standing herbage increased from 700 to $4300 \mathrm{~kg} \mathrm{DM} /$ ha (Figure $3 \mathrm{a}$ ). The CP content of the unpalatable fraction remained constant at $0.11 \mathrm{~g} / \mathrm{g}$ over the same range of standing herbage. The ME content of palatable (11.9 MJ/kg DM) and unpalatable fraction (7.9 MJ/kg DM) also remained constant as standing herbage accumulated (Figure 3b).

The percentage of palatable lucerne herbage decreased (0.012\% per $\mathrm{kg} \mathrm{DM} / \mathrm{ha}$, Table 3 ) from 100 to $57 \%$ as standing herbage accumulated from 700 to $4300 \mathrm{~kg} \mathrm{DM} /$

Figure 4 Percentage of (a) total herbage $(O,-)$ and (b) $\operatorname{CP}(0,--)$ and $\operatorname{ME}(O, \cdots)$ in the palatable fraction of lucerne from several regrowth cycles of crops grown at Lincoln University, Canterbury, New Zealand. Regression parameters are presented in Table 3.

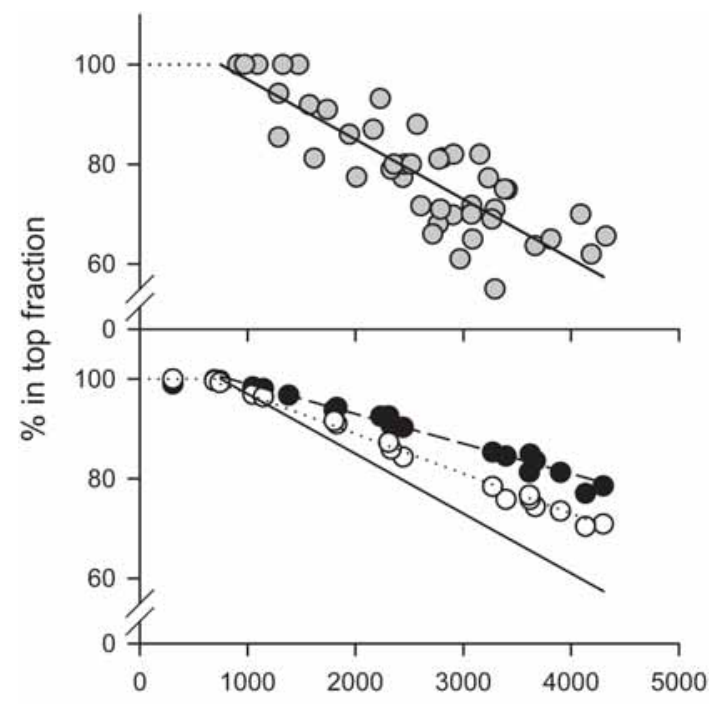

Standing herbage ( $\mathrm{kg} \mathrm{DM} / \mathrm{ha})$ 
ha (Figure 4a). The percentage of lucerne $\mathrm{CP}$ and ME in the palatable fraction (Figure $4 \mathrm{~b}$ ) also decreased beyond $700 \mathrm{~kg} \mathrm{DM} / \mathrm{ha}$, but CP decreased at $0.006 \%$ per $\mathrm{kg}$ to still contribute $80 \%$ of lucerne CP with $4300 \mathrm{~kg} \mathrm{DM} / \mathrm{ha}$ of standing herbage. Similarly, ME in the palatable fraction decreased at $0.008 \%$ per $\mathrm{kg}$ to contribute $70 \%$ of the total lucerne ME with $4300 \mathrm{~kg} \mathrm{DM} / \mathrm{ha}$ of standing herbage.

\section{Discussion}

The suitability of high quality forage systems on high value land is dependent on the relative benefits compared with other land uses. The results in this study provide a quantitative summary of the inputs and outputs from these perennial forages. Of these lucerne provided greater stock production potential than chicory or red clover.

\section{Herbage yield and stock intake}

The production advantage of lucerne came from 30\% higher annual herbage yields than chicory or red clover swards (Figure 1a), which resulted from earlier spring and later autumn growth (Brown et al. 2000). These yields were consistent with other literature for similar conditions (Allen et al. 1976; Douglas 1986; Hay \& Ryan 1989; Moloney \& Milne 1993) and highlighted the suitability of lucerne in this environment. The annual herbage yields were influenced by forage persistence and the subsequent invasion of less productive weed species. Red clover was the least persistent species and this reduced total herbage production. Weeds species were also less favoured by grazing stock and the reduced utilisation also contributed to the decline in herbage intake from red clover swards. Greater weed control may have been possible with a single species, particularly lucerne, where more appropriate crop specific herbicides could have been used.

\section{Potential production of grazing stock}

Comparative potential stock production was estimated from a combination of herbage intake and quality (ME and $\mathrm{CP}$ ). The palatable herbage fraction of all three species had similarly high ME (10.9-11.3 MJ/kg DM) contents, and lucerne and red clover also had high CP contents of $0.25-0.29 \mathrm{~g} / \mathrm{g}$ DM. This was consistent with their reputations as high quality forages (Barry 1998; Waghorn \& Barry 1987). The combination of a similar herbage quality and greater herbage intakes of lucerne gave $30 \%$ greater $\mathrm{CP}$ and ME intake than chicory or red clover. This implied greater potential stock production from lucerne although liveweight gain was not measured. The impact of the lower CP of chicory may be mitigated by its greater efficiency of use in the rumen (Komolong et al. 1992). Similar sheep growth rates have been shown from equal intakes of chicory or lucerne (Holst et al. 1998; Scales et al. 1995). However, it is still expected lucerne would support greater stock production than chicory through greater herbage intake.

The nutritive value of lucerne herbage within a regrowth cycle was also analysed to examine how the timing of grazing influenced the quality of herbage intake (palatable fraction). The $\mathrm{CP}$ content of the palatable fraction decreased to a stable $0.27 \mathrm{~g} / \mathrm{g}$ DM with $3000 \mathrm{~kg} / \mathrm{ha}$ standing herbage $\mathrm{DM}$. It is likely that $\mathrm{CP}$ contents greater than $0.27 \mathrm{~g} / \mathrm{g} \mathrm{DM}$ are higher than animal requirements for optimal growth (Waghorn \& Barry 1987). It follows that it may not be necessary to graze lucerne at early stages of regrowth $(<2500 \mathrm{~kg} \mathrm{DM} / \mathrm{ha})$ to capture the high $\mathrm{CP}$ content. Additionally, the ME in the palatable fraction of the lucerne was constant (11.5 MJ ME/ $\mathrm{kg} \mathrm{DM}$ ) as herbage accumulated. This indicates the time of grazing would not influence the ME content of herbage consumed by grazing sheep provided stock are removed before they have to consume the stem fraction.

The percentage of palatable lucerne herbage decreased over time indicating that delaying defoliation would decrease total herbage utilisation. However, the greater $\mathrm{CP}$ and $\mathrm{ME}$ contents of the palatable fraction meant total $\mathrm{CP}$ and ME utilisation decreased at a slower rate. Thus, a delay in grazing would only have small effects on the utilisation of total $\mathrm{CP}$ and $\mathrm{ME}$ from lucerne and will also maximise the potential animal production (CP and ME intake). These results indicate flexibility in the time of grazing with crops of $1000-4000 \mathrm{~kg} \mathrm{DM} / \mathrm{ha}$ all providing high quality herbage for stock. The management issue then relates to the utilisation of the standing lucerne and in particular the increasing proportion of unpalatable stem. However, grazing should not be delayed beyond the time of reaching ceiling yield at which point leaf-fall (Baars et al. 1990) will substantially reduce the quality of standing herbage.

\section{Feed conservation}

The greater herbage production of lucerne would also provide greater $\mathrm{ME}$ and $\mathrm{CP}$ for conserved feed production than chicory or red clover crops. There are two differences for conservation/supplementation systems that will affect stock production compared with a grazed system. Firstly, stock are less able to select the palatable fraction of chopped forage (van Keuren \& Matches 1988). This means the quality of herbage intake can be manipulated. Thus, a delay in mowing would give higher yields of lower quality herbage than early cutting. Also lowering mowing height will increase the fraction of lower quality stem in the harvested herbage, reducing quality. Secondly, conserved feed can be temporally transferred and different quality supplements can be used at strategic times (Burke et al. 2002). 


\section{The cost and value of production}

The cost and value of forage production, which can be incorporated into gross margins, can be used to compare the economics of using perennial forages with other options such as annual forage crops e.g. de Ruiter et al. (2002). The annual production from forage crops will vary with location. Lower yields would be expected where temperatures restrict the growing season and computer simulation models could be used to estimate potential production for individual locations. Lower yields would also be expected in dryland crops, particularly on soils of lower water holding capacity (Hayman 1985).

\section{Conclusions}

Of the forages tested lucerne had the highest potential stock production in an irrigated farm system:

- Annual DM yields of lucerne swards were 3-9 t/ha more than red clover and chicory over 5 years.

- Livestock intake of CP and ME from lucerne swards was 30\% higher than for chicory or red clover swards. Analysis of lucerne quality within regrowth cycles showed:

- The utilisation of total DM decreased from 100 to $57 \%$ as standing herbage accumulated from 700 to $4300 \mathrm{~kg} \mathrm{DM} / \mathrm{ha}$ and palatable herbage had a CP $\geq 0.27 \mathrm{~g} / \mathrm{g} \mathrm{DM}$ and an ME of $11.9 \mathrm{MJ} / \mathrm{kg} \mathrm{DM}$.

- The utilisation of total CP and ME was 80 and $70 \%$ (respectively) at $4300 \mathrm{~kg} \mathrm{DM} / \mathrm{ha}$ standing herbage due to the higher proportion of CP and ME in the palatable fraction of herbage. Thus, grazing may be delayed to maximise DM yields with little reduction in the utilisation of total ME or CP provided the unpalatable stem fraction is ungrazed.

\section{ACKNOWLEDGEMENTS}

Hamish Brown acknowledges the New Zealand Foundation for Science, Research and Technology for financial support during this study.

\section{REFERENCES}

Allen, R. B.; McDonald, I. R.; Cullen, N. A. 1976. Herbage production of pasture legumes at three sites in Otago. Proceedings of the New Zealand Grassland Association 37: 182-195.

Baars, J. A.; Douglas, J. A.; Knight, T.; Janson, C. G. 1990. Growth rates and relationships between weather and growth rates for lucerne (Medicago sativa L.) in Canterbury and the Rotorua - Taupo region. Proceedings of the New Zealand Grassland Association 52: 45-49.

Barry, T. N. 1998. The feeding value of chicory (Cichorium intybus) for ruminant livestock. Journal of Agricultural Science, U.K 131: 251-257.

Brown, H. E.; Moot, D. J.; Pollock, K. M.; Inch, C.
2000. Dry matter production of irrigated chicory, lucerne and red clover in Canterbury. Proceedings of the New Zealand Agronomy Society 30: 129-137.

Brown, H. E.; Moot, D. J.; Pollock, K. M. 2003. Long term growth rates and water extraction patterns of dryland chicory, lucerne and red clover. Legumes for dryland pastures. Grasslands Research and Practice Series 11: 91-99.

Brown, H. E. 2004. Understanding the yield and water use of dryland forage crops in New Zealand. Ph.D. thesis, Lincoln University. 305 pp.

Burke, J. L.; Waghorn, G. C.; Chaves, A. V. 2002. Improving animal performance using forage-based diets. Proceedings of the New Zealand Society of Animal Production 62: 267-272.

Buxton, D. R. 1996. Quality-related characteristics of forages as influenced by plant environment and agronomic factors. Animal Feed Science and Technology 59: 37-49.

Clapham, W.M.; Fedders, J.M.; Belesky, D.P.; Foster, J.G. 2001. Developmental dynamics of forage chicory. Agronomy Journal 93: 443-450.

Cox, J. E. 1978. Soils and agriculture of part Paparua County, Canterbury. New Zealand Soil Bureau bulletin No. 34. D.S.I.R, Wellington.

de Ruiter, J. M.; Hanson, R.; Hay, A. S.; Armstrong, K. W.; Harrison-Kirk, R. D. 2002. Whole-crop cereals for grazing and silage: balancing quality and quantity. Proceedings of the New Zealand Grassland Association 64: 181-189.

Douglas, J. A. 1986. The production and utilization of lucerne in New Zealand. Grass and Forage Science 41: 81-128.

Hay, R. J. M.; Ryan, D. L. 1989. A review of 10 years research with red clovers under grazing in Southland. Proceedings of the New Zealand Grassland Association 50: 181-187.

Hayman, J. M. 1985. The effect of irrigation interval and soil type on pasture and lucerne production. Proceedings of the New Zealand Grassland Association 46: 15-23.

Holst, P. J.; Kemp, D. R.; Goodacre, M.; Hall, D. G. 1998. Animal production in Australia. Proceedings of the Australian Society of Animal Production 22: 145148.

Komolong, M.; Nicol, A. M.; Poppi, D. P.; Fraser, T. J.; Kirsopp, S. 1992. Nutrient supply for lamb growth from Grasslands Puna chicory (Cichorium intybus) and Wana cocksfoot (Dactylis glomerata). Proceedings of the New Zealand Society of Animal Production 52: 85-87.

Li, G.; Kemp, P. D.; Hodgson, J. 1994. Control of reproductive growth in Puna chicory by grazing management. Proceedings of the New Zealand 
Grassland Association 56: 213-217.

Moloney, S. C.; Milne, G. D. 1993. Establishment and management of Grasslands Puna chicory used as a specialist, high quality forage herb. Proceedings of the New Zealand Grassland Association 55: 113-118.

Scales, G. H.; Knight, T. L.; Saville, D. J. 1995. Effect of herbage species and feeding level on internal parasites and production performance of grazing lambs. New Zealand Journal of Agricultural Research 38: 237-247.

van Keuren, R. W.; Matches, A. G. 1988. Pasture production and utilisation. pp. 515-538. In: Alfalfa and alfalfa improvement. Eds. Hanson, A. A.; Barnes, D. K.; Hill, R. R. J. American Society of Agronomy.
Madison, U.S.A.

Waghorn, G. C.; Barry, T. N. 1987. Pasture as a nutrient source. pp. 21-38. In: Feeding livestock on pasture. Ed. Nicol, A.M. Occasional Publication No. 10, New Zealand Society of Animal Production.

White, J. G. H.; Cosgrove, G. P. 1990. Lucerne grazing management. 2. Effect of grazing duration on defoliation pattern by ewes. New Zealand Journal of Agricultural Research 33: 621-625.

White, J. G. H.; Matthews, P. N. P.; Kemp, P. D. 1999. Supplementary feeding systems. pp. 175-198. In: New Zealand pasture and crop science. Eds. White J.G.H.; Hodgson, J. Oxford University Press, Auckland. 